\title{
Pro-Environmental Behaviour in Travel Mode Choice of Graduate Students: Case Study in Jakarta
}

\author{
Ankiet D. Lelono ${ }^{1,}$ Herdis Herdiansyah ${ }^{1 *}$, Linda Darmajanti ${ }^{2}$, Tri Edhi Budhi Soesilo ${ }^{1}$, \\ Hayati S. Hasibuan ${ }^{1}$ and Dwipayana ${ }^{1}$ \\ ${ }^{1}$ School of Environmental Science, Universitas Indonesia, Jalan Salemba Raya No. 4 Kampus UI \\ Salemba, Jakarta Pusat, 10430, Indonesia. \\ ${ }^{2}$ Department of Sociology, Universitas Indonesia, Kampus FISIP-UI, Depok, 16424, Indonesia.
}

\begin{abstract}
Rapid urban growth requires an established and dynamic transportation system to connect places and facilitate economic, social, cultural and human political activities. The choice of public transportation is considered a pro-environmental behavior in regards to emissions mitigation, therefore leads to sustainability. This paper attempts to understand graduate students' pro-environmental behavior in travel mode choice towards public transportation, and to observe correlation between socio-demographic factors and pro- environmental behavior. This research was conducted in University X in Jakarta with 82 respondents, analyzed in quantitative approach (SPSS) and mix method. Using Theory of Planned Behavior (TPB), this research concludes that attitude is the most dominant sub-variable of behavior, seen from correlation between attitude and subjective norm, intention, and respondents' age. Subjective norms and intention has positive correlation, but no correlation to socio-demographics.
\end{abstract}

\section{Introduction}

More than half of the world's population of 54\% is living in cities [1] resulting in consequence of increasing demand for public services [2] including public transportation. Indonesia has an intense urbanization rate of $48 \%$ in 2010 [3] with over $52 \%$ of its population living in the city in 2012 and is estimated about $68 \%$ of the population will be living in the city by 2025 [4]. Sustainable transportation is emphasized in accessible transportation for people in vulnerable circumstances [5]. However, transportation has impact on $\mathrm{CO} 2$ emissions. In 2014, CO2 emissions from the transport sector (percentage of total burning) of Indonesia is 30,807 ; higher than the world average of $\mathrm{CO} 2$ emission rate of 20,449 [1]. Indonesian transportation sector adds $70 \%$ to $80 \%$ in total outdoor air pollutant including destructive particulate matters, and motorized vehicle contributes $23 \%$ of greenhouse gas (GHG) emission [6].

\footnotetext{
* Corresponding author: herdis@ui.ac.id
} 
Transportation in Jakarta, Indonesia tends to be oriented towards private vehicles seen from the increasing trend of motorbike growth rate $10.54 \%$ per/year, followed by private car growth rate of $8.75 \%$ [7]. In 2014, motorbike dominates the road in Jakarta with a percentage of $74.67 \%$, followed by private car of $18.64 \%$ [7]. In relation to urban livability that reflects urban environmental aspects, Jakarta fails to fulfill the descriptions in regards to heavy congestion [6] and high pollution. In 47,5 million travels per/day made in greater Jakarta (Jabodetabek-Jakarta Bogor Tanggerang Bekasi) in 2015, only 2\% used public transportation [8]. In addition, active transportation (cycling and walking) is an uncommon mode of traveling in Jakarta.

Jakarta's transportation mode consists of public transport (Bus Rapid Transportation/BRT i.e. TransJakarta, commuter line) and other types of public transportation (e.g bus and mikrolet), online transportation, and private vehicles (motorbikes and cars). This article specifies public transports in terms of BRT and commuter line. This article focuses on graduate students' travel-mode choice at the University X in Jakarta, being one of major universities in Indonesia that holds graduate and post graduate studies. This research was conducted using the Theory of Planned Behavior (TPB) [9][10] that posits a model to measure how human actions is guided, and predicts the occurrence of a particular behavior, stating that behavior is intentional and rational.

Pro-Environmental or environmental behavior is a form of environmentally oriented action in minimizing the negative impacts of individual action on the natural and artificial environment [11]. Any action performed individually or collectively towards environment may cause in direct or indirect result in mitigating harm, or improving the environment [12]. It can be predicted by psychological constructions in terms of attitudes, beliefs, and values [13] which then specifically measured in this study through Theory of Planned Behavior (TPB). TPB by Ajzen [9][10] states that individual's behavioral intention to perform a behavior is influenced by three main predictors, namely: attitude toward behavior, subjective norm, and perceived behavioral control. Behavior generally rises from rational considerations based on available information, and from consideration concerning potential consequences of behavior. TPB is considered useful in predicting pro-environmental behavior and successfully explains the travel behavior and the individual's travel mode choice [9][14].

Travel mode choice can be considered as a significant pro-environmental behavior in the way it affects the environment [15]. The choice of environmental-friendly or proenvironmental transportation mode can occur based on a moral obligation to act sustainably [15]. Measurement on the travel mode behavior could be beneficial in effort to influence people to travel in a sustainable manner [14]. In addition, socio-demographic factors and personal characteristics of commuters, such as age and physical condition, are known to influence travel mode choice [16]. In Indonesian context, particularly in Jakarta, online transportation has grown popularity amongst other transportation mode. Online transportation or ride-share is an individual on-demand [17] transportation service accessible through app [18]. Differ from European or North American online transportation based in car ride-share services, online transportation in Indonesia pioneered by Go-Jek in 2010 utilizes motorbike taxi or called "ojek" in local vernacular, as well as car.

The ride-hailing motorbike service offers wide range services from transporting passengers, to delivering food, meal, grocery (gojek.com; grab.com), medicine, hairstylist, and auto and house cleaning services in greater Jakarta (gojek.com). Other major competitor is Grab. Using "ojek", together they become a favorite alternative to existing travel mode choices by offering a comparatively shorter travel time compared to car or car taxi in highly congested Jakarta. They offer ride to BRT and commute line stations and in so doing, it assists individual to use public transportation. 
Studies have been conducted with regards to pro-environmental behavior in travel mode choice [19][20], that specifically uses TPB [14], and focuses on students [21]. Similar researches seek to understand pro-environmental behavior on graduate students have been widely applied on various topics. In Brazil, one study [22] shows that women perform more intensively than men with regard to effective practice of social transformation regarding environmental issues. Study in Turkey [23] concludes that graduate students as teachers or academics for the future, have positive awareness towards sustainable development. Study in India [24] finds significant correlation between level of environmental awareness and the frequency of reported environment related behavior. Study in Budapest [25] finds that biospheric value orientations and a close personal bond with nature can provide a basis for the development of pro-environmental behavior. One research in China [26] finds that proenvironmental behavioral intentions range from medium to high; and another [27] finds that pro-environmental behaviors are more likely to occur than awareness.

Drawing from aforementioned studies, little attention has been given to research on similar topics in Indonesia. To the authors' knowledge, measurement of pro-environmental behavior in travel mode choice is non-existing in Indonesia, and this research aims to fill the gap by focusing on graduate students to understand their behavior towards public transportation. This article seeks to investigate correlation between demographic factors and behavior. This research suggests that public transportation is a more sustainable travel mode choice than private vehicles.

\section{Research methods}

\subsection{Data collecting}

This research was conducted by adopting the quantitative approach using questionnaires and in mixed method to take the overall strength of both quantitative and qualitative. Samples were obtained from purposive sampling on graduate students at the University X in Jakarta consisting of 82 graduate students from various educational background $(n=82)$ in the third week of February 2018. This research chose University X in Jakarta for the reason that University $\mathrm{X}$ in Jakarta is located in one of Jakarta's center of activities with busy traffic of motorized vehicles and its proximity to public transportation. This study selected graduate students as research population because students studying in universities are encouraged to perform pro-environmental behavior [28]. Further, what a student believes or does have an impact on his/her future life [29] e.g students who choose to be punctual will continue to practice this punctuality when they graduate and work. Graduate students refer to students who have already obtained bachelor degrees and are working on their master or doctoral degree. Prior to field work, questionnaire was tested its reliability and validity test using Cronbach's alpha and composite reliability resulted in Cronbach's alpha 0.883 coefficient showing validation.

\subsection{Data processing}

All TPB components were measured in questionnaire with Likert scale in 4 categories: Strongly Agree, Agree, Disagree, and Strongly Disagree. This study excluded the Neutral scale $(\mathrm{N})$ on consideration that 'neutral' answers are not fully neutral since they tend to lean toward 'agree' of 'disagree'. Data were analyzed using IBM SPSS version 22 [30] to measure correlation between variables and sub-variables. 


\section{Result and discussion}

This study aims to investigate three reasons. Firstly: pro-environmental behavior in travel mode choice; secondly: correlation between pro-environmental behavior with sociodemographic characteristics (age, sex, marital status, education level, and education background); and thirdly: correlations between sub-variables of behavior. Sociodemographic characteristics of populations are presented in Table 1. Correlation test was conducted with Spearman Rank with 95\% confidence level $(\alpha=0.05)$. Table 2 shows a positive and moderately strong correlation between attitudes with subjective norms. It also shows a positive and moderately strong correlation between attitude and strong intention; which is in line with findings in previous research [16].

Table 1. Sample Socio-Demography $(\mathrm{n}=82)$

\begin{tabular}{|l|l|l|l|}
\hline Variable & Category & Frequency & Percent (\%) \\
\hline Age & $21-30$ & 42 & 51.2 \\
& $31-40$ & 28 & 34.1 \\
& $41-50$ & 9 & 11.0 \\
& $51-60$ & 3 & 3.7 \\
\hline Sex & Male & 54 & 65.9 \\
& Female & 28 & 34.1 \\
\hline Education (last & Bachelor & 27 & 32.9 \\
obtained degree) & Master & 55 & 54.9 \\
\hline Marital status & Married & 37 & 45.1 \\
& Single & 45 & 54.9 \\
\hline Educational & Medical & 25 & 30.5 \\
background & Economy & 12 & 14.6 \\
(major) & Law & 11 & 13.4 \\
& Engineering & 14 & 17.1 \\
& Social Sciences & 20 & 24.4 \\
\hline
\end{tabular}

This research found a positive and moderately strong correlation between subjective norms and intention. However, no correlation was found between perceived behavior and other behavior sub-variables (subjective norms, attitude, intention). Interviews from a number of informants helped explain the constraints faced by public transport. "I'm not keen to use public transportation because some bus stops/train stations are dirty."; "Actually BRT and commuter line are pretty good, but they lack feeder busses to and from bus stops/train stations."; "Although the commuter line schedule is more punctual now, but schedule from Cikini (Jakarta) to Maja (Tangerang) is still intermittent and not evenly distributed, so if I am 5 minutes late from $6.40 \mathrm{pm}$, I have to wait 1 hour 25 minutes until the next train comes at 8:05 pm." (Commuter schedule line can be accessed at http://www.krl.co.id/\#m perjalanankrl). Statements from informants show some reluctance in choosing public transportation caused by various situational factor. They are: dirty conditions of train stations/bus stops, access, and schedule; all of which are situational factors consisting provision of transportation mode infrastructures, travel characteristic, transit accessibility, and transit costs [31].

Respondents were also asked about their past reports in using public transport in the last 30 days. Table 2 shows that most graduate students only used public transportation (BRT and commuter line) for 0-3 days in the last 30 days. Table 3 illustrates that past report of travel mode choice towards public transportation is low. This result is supported by University X parking lot being always full and cannot accommodate cars and motorbikes. As a parking 
cashier noted: "Especially in the morning from 06.30 to 09.30 am and in the afternoon at $03.00 \mathrm{pm}$ to $06.00 \mathrm{pm}$, many cars are not able to park here, so I tell them to try parking in the adjoining buildings."; and as at least 30 students said: "It's difficult for me to park my car, especially if I have morning class, if I got here past 7 AM, I'd better go straight to nearby buildings to park my car there."

Table 2. Past Report in public transportation choice in the last 30 days $(\mathrm{n}=82)$

\begin{tabular}{|l|l|l|}
\hline Category & Frequency & Percent $(\%)$ \\
\hline $0-3$ times & 44 & 53.7 \\
\hline $4-10$ times & 23 & 28.0 \\
\hline $11-20$ times & 11 & 13.4 \\
\hline $21-30$ times & 4 & 4.9 \\
\hline Total & 82 & 100 \\
\hline
\end{tabular}

*. Correlation is significant at the 0.05 level (2-tailed).

**. Correlation is significant at the 0.01 level (2-tailed).

Table 3. Correlation in Theory of Planned Behavior ( $\mathrm{n}=82$ ) with Spearman's rho

\begin{tabular}{|c|l|l|l|l|}
\hline No. & Variable X & \multicolumn{1}{c|}{ Variable Y } & \multicolumn{1}{c|}{ Correlation } & P value \\
\hline 1 & Subjective Norm & Attitude & $0,554^{* *}$ & 0,000 \\
\hline 2 & Perceived Behavior & Attitude & 0,196 & 0,077 \\
\hline 3 & Intention & Attitude & $0,589^{* *}$ & 0,000 \\
\hline 4 & Attitude & Subjective Norm & $0,554^{* *}$ & 0,000 \\
\hline 5 & Perceived Behavior & Subjective Norm & 0,005 & 0,965 \\
\hline 6 & Intention & Subjective Norm & $0,726^{* *}$ & 0,000 \\
\hline 7 & Attitude & Perceived Behavior & 0,196 & 0,077 \\
\hline 8 & Subjective Norm & Perceived Behavior & 0,005 & 0,965 \\
\hline 9 & Intention & Perceived Behavior & 0,195 & 0,080 \\
\hline 10 & Attitude & Intention & $0,589^{* *}$ & 0,000 \\
\hline 11 & Subjective Norm & Intention & $0,726^{* *}$ & 0,000 \\
\hline 12 & Perceived Behavior & Intention & 0,195 & 0,080 \\
\hline
\end{tabular}

*. Correlation is significant at the 0.05 level (2-tailed).

**. Correlation is significant at the 0.01 level (2-tailed).

Moreover, some respondents claimed that they chose using their private cars even though they have to face daily congestion. One informant said: "I live in Bekasi and I usually have early classes or assignments at 9 AM. That means I have to hit the road approximately at 55.15 AM to avoid heavy congestion. But it's better than to jostling in buses. Public transport is inconvenient here in Jakarta. My car is more comfortable." This and other similar statements confirm finding about priority of travel comfort [32]

Other informants even compared public transport in Jakarta to abroad. "When I lived in Singapore for almost a year taking a course, I took public transport. But it was clean and punctual there.". "I stayed in Europe for two months visiting my aunt, and I took trains and buses. They were nice, clean, punctual, and most importantly, safe. So, no. I am not keen on using public transport here." And some preferred motorbike over public transportation due to its practicality: "To be fair, public transport and motorbike are cheap. But I'd prefer riding my bike." This statement confirms a study that states motorbike could act as an alternative transportation mode that answers public transportation's failure as well as to break through congestion in Asian cities[33] including Jakarta. Some car users also confessed that they used their own private cars as signs of privilege or social status which is in line with previous studies [34][19]. 
After analyzing bivariate correlation between socio-demographic components and behavior, and sub-variables of behavior, SPSS showed no correlation, excepting a positive and weak correlation between age and attitude as shown in table 4 below. Further, no correlation between past report and behavior was found.

Table 4. Correlation between Age Sub-variable and Theory of Planned Behavior ( $n=82)$

\begin{tabular}{|c|c|c|c|c|c|c|}
\hline \multicolumn{2}{|c|}{} & Age & Attitude & $\begin{array}{c}\text { Subjective } \\
\text { Norm }\end{array}$ & $\begin{array}{c}\text { Perceived } \\
\text { Behavior }\end{array}$ & Intention \\
\hline Age & $\begin{array}{c}\text { Correlation } \\
\text { Coefficient }\end{array}$ & 1.000 & $.263^{*}$ & .132 & -.022 & .153 \\
\hline & $\begin{array}{c}\text { Sig. (2-tailed) } \\
\end{array}$ & & 0.17 & .236 & .846 & .169 \\
\hline
\end{tabular}

*. Correlation is significant at the 0.05 level (2-tailed).

**. Correlation is significant at the 0.01 level (2-tailed).

Higher education institution both in formal and non formal, has begun to practice proenvironmental or environmental friendly principles [35], library management, and infrastructure and parking. It suffices to suggest that pro-environmental behavior will continue to progress to better direction.

\section{Conclusion}

This research concludes that attitude is the most dominant sub-variable of behavior seen from correlation between attitude and subjective norm, intention, and respondents' age. Subjective norms and intention has positive correlation, but no correlation to socio-demographics (age, sex, marital status, education level, and education background). This research has gained understanding that graduate students' pro-environmental behavior is low. Drawing from finding that even though University $\mathrm{X}$ has good access to good public transportation (BRT and commuter line), many students are reluctant to use public transport due various situational factors, namely: dirty station, lack of feeder busses, and poor schedule. These cause graduate students to prefer private vehicle (motorbikes and cars) over public transportation, shown by the full parking lot. This research exempted questions to respondents whether they owned private vehicle. Hence, correlation between vehicle ownership and behavior was unmeasured. This study has another limitation in small sample size of 82 respondents. Further study should be conducted using probability method with larger samples to perform inferential statistical analysis to predict students' behavior in general population. Subsequent research could include online transportation as intervening variable to determine its effect on public transportation and private vehicles. Despite the unclear definition of online transportation category in transportation and its contribution to emission mitigation, it is an interesting phenomenon that needs to be examined in relation to its function and position in sustainable transportation.

This research is funded by the Grant of Indexed International Publication for Final Project of Students/Publikasi Terindeks Internasional Untuk Tugas Akhir Mahasiswa (PITTA) Universitas Indonesia 2018 with contract number 2577/UN.R3.1/HKP.05.00/2018. 


\section{References}

1. UN-DESA. World's population increasingly urban with more than half living in urban areas. http://www.un.org/en/development/desa/news/population/worldurbanization-prospects-2014.html, (2014)

2. UNFPA, State of world population 2011. People and Possibilities in a World of 7 Billion. New York: United Nations Population Fund, (2011)

3. World Bank. INDONESIA RISING. Policy Priorities for 2010 and Beyond. Creating World-Class, Competitive and Liveable Cities. Jakarta: World Bank. http://www.worldbank.org/id, (2010)

4. World Bank IEA Statistics. 2014. CO2 emissions from transport (\% of total fuel combustion)

https://data.worldbank.org/indicator/EN.CO2.TRAN.ZS?end $=2014 \&$ locations $=\mathrm{H}$ U-ID\&start $=1965 \&$ view $=$ chart, $(2014)$

5. World Bank. A Global Opportunity for Sustainable Transport. http://www.worldbank.org/en/news/feature/2015/07/31/a-global-opportunity-forsustainable-transport, (2015)

6. Asian Development Bank, K.H Leung. . 15. Asian Development Bank. (2016)

7. BPS Provinsi Jakarta. Transportation Statistics Jakarta, (2015)

8. BPTJ (Badan Pengelola Transportasi Jabodetabek)/Jabodetabek Transportation Authority (JTA).. http://bptj.dephub.go.id/?p=1409 ,accessed on March 52018. (2017)

9. I. Ajzen.. Org Beh and Hum Dec P, 50 (1991)

10. I. Ajzen, B.L Driver.. J. Leis. Res. 24 (3), 207-224.(1992)

11. A. Kollmuss, J. Agyeman. Environ Educ Res, (2002)

12. Jensen BB. behaviour. Environ Educ Res, 8, 3 (2002)

13. Groot, J.I.M., Steg, L.. Jou of Env Psy 30, 4 (2010)

14. S.L. Lo, , G.J.P. van Breukelen, G-J. Y. Peters, G. Kok. Trav Beh and Soc 4. (2015)

15. P. C. Stern,.. Jour of Soci Iss, 56 (2000)

16. K. Xie, H. Xiong, C. Li. (ISC2). IEEE, (2016)

17. C. Watanabe, K. Naveed, P. Neittaanmäki,. Tech in Soc, 46, 164-185. (2016)

18. S. Wallsten, S.. Tech Pol Ins, 22. 33. (2015).

19. T. Nordfjærn, Ö. Simsekoglu, T. Rundmo. Transp Res Part F 42 70-79 (2016)

20. O.A. Bjørkelund, H. Degerud, E. Bere. Arc of Pub H, (2016)

21. S. Murtagh, D. A. Rowe, M. A. Elliott, D. McMinn, N. M. Nelson. Int Jour of Beh Nut and Phy Ac, (2012)

22. D.M de Almeida, M. da Gama, L.R. Lopes, L.F.D. Avila, T.K.R Ibdaiwi. Env Qual Man, (2016)

23. S. Özgürler, A. Cansaran, A. (2014). Graduate Students, Study Of Environmental Literacy and Sustainable Development. International Electronic Journal of Environmental Education, 4, 2 (2014)

24. Sengupta, Madhumala., Das, Jayanti., Maji, Pintu Kumar.. Anwesa, 5 (2010)

25. M. Piskóti... nstitute of Marketing and Media Department of Marketing Research and Consumer Behaviour. Budapest, (2015)

26. Su-Lan Pan, Ju Chou, Alastair M. Morrison, Wen-Shiung Huang, Meng-Chen Lin.?. Sustainability 10, (2018)

27. Liping Fu, Ye Zhang, Xiong Xiong, Yin Bai.. EUR Jou of Mat, Sci and Tech Ed 77953 (2018)

28. B. Thapa. Environmentalism: Tech \& Soc, 19 (1999)

29. J. L. B. Carlos, Trans Pol 10, 1 (2003) 
30. IBM Corp., IBM SPSS Statistics for Windows, Version 22.0. Armonk, NY: IBM Corp, (2013)

31. R. Ewing, W. Schroeer., W. Greene.. Trans Rese Rec 1895, 1 (2004)

32. T. Rundmo, J.F. Sigurdson, I. Cerasi-Roche. Trondheim: Rotunde Publ. (2011).

33. Tuan, Vu Anh, Iderlina B. Mateo-Babino. " Jou of the East A Soc for Transp Stud 10:13-28. (2013)

34. Steg, L. Car use: Lust and must. Trans Res Part A: Pol and Prac, 39,147-162. (2005)

35. Herdis Herdiansyah et al. IOP Conf. Ser.: Earth Environ. Sci. 30 (2016) 